\title{
Perlindungan Hukum Saksi Dan Korban Pada Pengungkapan Kasus Korupsi Berdasarkan Undang - Undang Nomor 13 Tahun 2006 Tentang Perlindungan Saksi Dan Korban
}

\author{
Mangatur Hadiputra Simanjuntak \\ Magister Ilmu Hukum Universitas Diponegoro Semarang \\ simanjuntakmangatur@yahoo.co.id
}

\begin{abstract}
Witness or whistleblower is one of the keys for the judges to hammer out a matter particularly strange a matter involving many people, groups, or the throne. So are the perpetrators of a witness cooperating (justice collaborator). Both very vital role in the trial in exposing a case of crime. In the development of the law itself, practitioners and law enforcers are aware of correct the need for protection for the witnesses and justice collaborator. However, to this day there has not been any legislation governing the protection for whistleblowers and collaborator of justice itself. This research aims to know the extent to which the application and implementation of the Supreme Court Circulars No. 4 Year 2011 about Treatment For Reporting criminal act (whistleblowers) and witnesses the perpetrators who are willing to cooperate (justice collaborator) in certain criminal acts especially criminal acts of corruption. To achieve the objectives of this research, the author then use the normative juridical approach. A collaborator of justice is an essential component in the disclosure of a corruption case. Become important because they get involved in such cases and is considered the most knowing how such cases happen, whoever the perpetrators, and where the flow of funds that they selewengkan. A true collaborator of justice should obtain a special protection from the law enforcers. However, the existence of the SEMA 4/2011 this does not yet have a binding force as laws that cause much of a difference of interpretation in its application so that it can be rarely enforced.
\end{abstract}

Keywords: witness, victim, corruption

\begin{abstract}
Abstrak
Saksi atau whistleblower merupakan salah satu kunci bagi para hakim untuk menuntaskan sebuah perkara khususnya suatu perkara pelik yang melibatkan banyak orang, kelompok, atau kekuasaaan. Begitu juga seorang saksi pelaku yang bekerja sama (justice collaborator). Peran keduanya sangat vital dalam persidangan dalam mengungkap suatu kasus kejahatan. Dalam perkembangan hukum itu sendiri, para praktisi dan para penegak hukum menyadari betul perlunya perlindungan bagi para saksi dan justice collaborator. Namun, sampai hari ini belum ada satu pun undang - undang yang mengatur tentang perlindungan bagi justice collaborator dan whistleblower itu sendiri. Penelitian ini bertujuan untuk mengetahui sejauh mana penerapan dan implementasi dari Surat Edaran Mahkamah Agung Nomor 4 Tahun 2011 tentang Perlakuan Bagi Pelapor Tindak Pidana (whistleblower) dan saksi pelaku yang mau bekerjasama (justice
\end{abstract}


collaborator) dalam tindak pidana tertentu khusunya tindak pidana korupsi. Untuk mencapai tujuan penelitian ini, maka penulis menggunakan pendekatan yuridis normatif. Seorang justice collaborator adalah komponen penting dalam pengungkapan suatu kasus korupsi. Menjadi penting karena mereka ikut terlibat di dalam kasus tersebut dan dianggap yang paling mengetahui bagaimana kasus tersebut terjadi, siapa saja para pelakunya, dan kemana aliran dana yang yang mereka selewengkan. Seorang justice collaborator sejatinya harus mendapatkan suatu perlindungan khusus dari para penegak hukum. Namun, eksistensi SEMA 4/2011 ini belum memiliki kekuatan yang mengikat seperti undang - undang yang menyebabkan dalam penerapannya banyak perbedaan interpretasi sehingga jarang sekali dapat ditegakkan.

\section{Kata Kunci: Saksi, Korban, Korupsi}

\section{Pendahuluan}

Tindak pidana korupsi seakan menjadi masalah serius yang menjangkiti banyak negara di dunia ini tak terkecuali negara Indonesia. Kejahatan yang akhir - akhir ini dilabeli oleh pemerintah sebagai kejahatan luar biasa ini memang menjadi salah satu masalah besar di Indonesia yang harus segera diselesaikan.. Maraknya kasus tindak pidana korupsi yang terjadi bahkan memperlihatkan peningkatan jumlah kasus yang terungkap dari segi kuantitas dan kualitas semakain masif.

Korupsi seolah-olah menjadi sebuah hal yang lumrah dan lazim terjadi di negara kita. Bahkan kita sering dipertontonkan kasus - kasus yang terjadi ini banyak melibatkan unsur penegak hukum. Kasus yang terjadi bukan hanya melibatkan individu tertentu, tetapi juga terjadi secara terstrukur dan masif. Mereka menjadikan kekuasaaan dan kewenangan yang diperoleh untuk melegalkan berbagai kejahatan korupsi itu sendiri. Mereka seperti berkolaborasi, saling menutupi dan saling melindungi untuk menutupi kejahatan yang mereka lakukan. Maraknya pemberitaan di media mengenai jual beli perkara, mafia hukum, mafia peradilan, mafia pajak, dan berbagai kasus lainnya, mengindikasikan bahwa korupsi telah menjangkiti hukum itu sendiri. Masih segar dalam ingatan kasus korupsi mega proyek hambalang yang bernilai triliunan rupiah, kasus korupsi bantuan likuiditas Bank 
Indonesia atau BLBI yang juga belum terselesaikan dengan tuntas.

Kasus-kasus ini terjadi dengan banyak melibatkan tokoh besar yang seharusnya menjadi contoh teladan bagi masyarakat. Fakta dari tahun ke tahun menunjukan kasus kejahatan korupsi semakin marak terjadi. Ratusan anggota DPRD, DPR, DPD, Bupati, Walikota bahkan Gubernur hingga ketua Mahkamah Konstitusi tertangkap. Artinya, korupsi ini banyak melibatkan berbagai institusi dan lembaga negara. Sangat terstruktur dan masif. Bahkan dalam prakteknya mereka kerap berkolaborasi dan saling melindungi. Ini artinya masalah terjadi semakin lama semakin memprihatinkan. Keboborokan moral, penerapan hukum yang lemah seperti menjadi biang masalah yang terjadi. Apabila masalah ini terus dibiarkan, maka akan sangat berbahaya bagi kelangsungan demokrasi negara itu sendiri, sendi - sendi negara akan hancur, dan yang paling terdampak adalah masyarakat banyak karena ini menyangkut rasa keadilan dan kesejahteraan.

Para penegak hukum pun tidak lepas dari kejahatan ini. Mereka yang seharusnya menjadi benteng peradilan dan hukum ikut terjangkit dalam berbagai kasus tindak pidana korupsi. Mulai dari unsur di kepolisian, kejaksaan dan pengadilan. Godaan ini datang ketika mereka menangani berbagai kasus kasus besar yang melibatkan banyak elit dan pejabat di pemerintah yang notabene mempunyai kekuatan finansial yang besar. Mereka terkena berbagai kasus suap dalam melindungi, meringankan, dan berusaha untuk bisa membebaskan para tersangka dan terdakwa dari tuntutan hukum. Hukum seolah bisa dibeli dan dipermainkan ketika mereka di iming - imingi berbagai "hadiah" apabila para penegak hukum ini bisa membantu dan menolong mereka lepas dari jeratan hukum.

Anggaran yang seharusnya dipakai untuk berbagai macam aktivitas negara, kelembagaan, pembangunan infrastruktur, pengembangan dana pendidikan raib oleh mereka yang tidak bermoral. Pada tahun 2012 lalu tercatat Indonesia menempati urutan 118 
dari 182 negara. Dilihat dari indeks korupsi yang dikeluarkan oleh Transparency International, tercatat pada tahun 2015 lalu Indonesia mengalami peningkatan pengurangan kasus korupsi dimana pada tahun tersebut mengalami peningkatan dari posisi 114 ke posisi 107. Namun apabila dibandingkan dengan negara tetangga seperti Malaysia, Thailand, Singapura, Filipina. Artinya, posisi ini masih dalam posisi yang memprihatinkan dibandingkan negara tetangga tersebut. Bukan hanya menyengsarakan rakyat, dampak yang terjadi juga terjadi pada iklim bisnis. Korupsi yang marak terjadi akan membuat investor ragu untuk berinvestasi di Indonesia khususnya investor asing. Bukan rahasia umum lagi bahwa agar segala sesuatunya berjalan lancar, berlaku pepatah "kalau bisa dibikin sulit, mengapa harus dibikin mudah". Selain itu, banyak terjadi di berbagai sektor dan instansi pemerintah dimana tujuannya jelas agar para investor mengeluarkan banyak biaya untuk mengurus berbagai perizinan agar dipermudah dan dipercepat sehingga "dwelling business" di
Indonesia menjadi sangat mahal bagi mereka.

Dalam penegakan hukum korupsi, peran saksi dalam setiap masalah kasus hukum korupsi memilki peran yang sangat besar dan signifikan dalam mengungkap kasus kasus yang terjadi. Hakim tentu akan memilki sudut pandang dan referensi yang lebih luas guna mendapatkan berbagai macam alat bukti yang bisa dipakai untuk menjerat para tersangka dan terdakwa. Seringkali dalam persidangan, para saksi ini merasa terancam akan keselamatan nya juga orang terdekatnya apabila mereka membeberkan fakta yang mereka lihat dan yang mereka ketahui. Apalagi ketika kasus yang terjadi melibatkan orang besar yang mempunyai kekuasaaan dan mempunyai kekuatan finansial yang kuat.

Saksi atau whistleblower merupakan salah satu kunci bagi para hakim untuk menuntaskan sebuah perkara khususnya suatu perkara pelik yang melibatkan banyak orang, kelompok, atau kekuasaaan. Begitu juga seorang saksi pelaku yang bekerja sama (justice collaborator). 
Peran keduanya sangat vital dalam persidangan dalam mengungkap suatu kasus kejahatan. Seorang justice collaborator tentu juga mengetahui bagaimana kasus korupsi itu bisa terjadi, siapa saja perannya dan siapa saja yang menerima aliran dana tersebut karena dirinyalah yang mengetahui salah satu pelaku. Namun, seringkali dalam persidangan, kedua peran ini mendapat banyak tekanan dari kelompok atau orang yang tidak senang jika kasus tersebut dibongkar. Seringkali mereka mendapat ancaman berupa teror fisik maupun mental agar kesaksiannya tidak disampaikan.

Dalam perkembangan hukum itu sendiri, para praktisi dan para penegak hukum menyadari betul perlunya perlindungan bagi para saksi dan justice collaborator. Namun, sampai hari ini belum ada satu pun undang - undang yang mengatur tentang perlindungan bagi justice collaborator dan whistleblower itu sendiri. Memang aturannya secara implisit terdapat dalam Undang - Undang Nomor 13 Tahun 2006 tentang Perlindungan
Saksi dan Korban yang selanjutnya UU PSK. UU PSK tersebut diikuti dengan SEMA Nomor 4 Tahun 2011 tentang Perlakuan Terhadap Whistleblower Dan (Justice Collaborator).

Dalam beberapa kasus atau perkara yang terjadi, seorang justice collaborator sering kali hanya dijadikan sebagai martir untuk menutupi kasus yang terjadi oleh atasannya atau kelompok lain yang memiliki power yang lebih kuat baik itu secara finansial, jabatan, akses kepada elit politik yang berkuasa di pemerintahan dan sebagainya agar tidak membawa dan menyeret mereka ke pusaran kasus yang sedang berlangsung. Namun, juga dalam beberapa kasus lain, mereka merupakan aktor utama dalam kasus korupsi tersebut yang mengetahui betul dengan sangat baik bagaimana kasus tersebut bisa terjadi.

Tentu keberanian dari mereka untuk membeberkan apa yang sebenarnya terjadi harus mendapat apresiasi berupa perlindungan hukum yang kuat baik kepada mereka maupun kepada orang terdekatnya menyangkut keselamatan jiwa 
mereka. Namun, terkadang tekanan yang sangat kuat dari pihak tidak ingin kasusnya diungkap membuat mereka enggan untuk membeberkan apa yang terjadi. Tentu masih belum hilang dari ingatan bahwa seorang Muhammad Nazarudin berani bersaksi dan membeberkan siapa saja yang menerima aliran dana mega proyek hambalang yang nilainya triliunan rupiah. Setelah kesaksian tersebut, satu persatu elit politik khususnya yang berada lembaga legislatif ditangkap dan dijadikan terdakwa.

Namun juga berembus kabar yang kurang baik bahwa kasus tersebut tidak benar diungkap secara terang benderang. Masih banyak tokoh yang berkeliaran bebas tidak terjerat, dan banyak yang merasa dikorbankan untuk melindungi elit elit yang lebih tinggi dan berkuasa.

Tentu sebagai masyarakat kita selalu berharap bahwa setiap kasus hukum yang terjadi khususnya mengenai tindak pidana korupsi, baik itu melibatkan tokoh besar, elit partai atau pun elit politik, orang atau kelompok yang berkuasa di pemerintahan juga pihak swasta, siapapun yang terlibat harus diberikan ganjaran hukuman yang setimpal. Hukum berlaku bagi siapapun tidak memandang golongan, kaya atau miskin, elit atau bukan, berkuasa atau tidak dan sebagainya karena ini merupakan kejahatan luar biasa yang harus dituntaskan.

Dengan demikian, dari berbagai fakta dan teori yang penulis ungkap diatas dalam hal ini penulis coba untuk merumuskan masalah yang akan di bahas dalam artikel ini yaitu (1) perlindungan hukum terhadap keberadaan saksi dan korban sebagai whistleblower dan justice collaboratos pada pengungkapan korupsi, (2) hambatan perlindungan hukum kepada whistleblower dan justice collaborators pada pengungkapan kasus korupsi.

\section{Metode Penelitian}

Dalam penelitian ini, penulis menggunakan metode pendekatan hukum normatif dimana penjelasan yang penulis akan uraikan ialah berdasarkan fakta yang faktual dan juga contoh kasus yang terjadi belakangan ini. Adapun bahan yang 
akan penulis gunakan dalam mengurai masalah yang terjadi juga sebagai pedoman dan referensi penulis dalam menulis karya ilmiah ini adalah bahan hukum berupa hukum primer yaitu perundangundangan, bahan hukum sekunder yaitu artikel dna putusan pengadilan

\section{Hasil dan Pembahasan}

Perlindungan Hukum Terhadap Keberadaan Saksi Dan Korban Sebagai Whistleblower dan Justice Collaborators Pada Pengungkapan Korupsi di Indonesia Berdasarkan Undang-Undang Nomor 13 Tahun 2006 Tentang Perlindungan Saksi Dan Korban

\section{Keberadaan}

whistleblower dan

seorang

collaborators dalam suatu perkara di persidangan sangat mutlak diperlukan oleh para hakim pengadilan untuk mencari bukti dan fakta yang terjadi dalam suatu masalah tindak pidana korupsi. Namun, faktanya sering kali para whistleblower ini enggan atau takut untuk mengatakan fakta yang sebenarnya dan dihadirkan dalam persidangan untuk mengungkapkan apa yang dia lihat dan dia tahu. Dalam perjalanannya, mereka sering kali merasa takut karena harus menghadapi kekuatan, kelompok atau orang yang yang mempunyai pengaruh yang kuat baik dari segi finansial, jabatan lembaga atau instansi dan afiliasi kepada kelompok politik yang kuat khusus nya di pemerintahan bahkan sering kali dalam perjalanannya, status hukum dari seorang whistleblower tersebut tidak berhenti hanya sebatas whistleblower saja bahwa suatu saat kedudukan tersebut dapat berubah menjadi seseorang yang harus dimintai pertanggungjawaban pidana.

Sama halnya dengan seorang justice collaborator juga memeliki peran penting dalam mengungkap suatu kejahatan korupsi yang terjadi. Ia dianggap sangat mengetahui betul detail yang terjadi mulai dari rencana yang disusun, implementasi dari korupsi itu sendiri, juga kemana aliran dana itu mengalir. Namun, dalam perjalanannya perlindungan hukum bagi seorang justice collaborator masih sangat lemah. di dalam Indonesia. Pengaturan mengenai justice collaborator terdapat dalam ketentuan UU PSK, 
Surat Edaran Mahkamah Agung Nomor 04 Tahun 2011 tentang Perlakuan Bagi Pelapor Tindak Pidana dan Saksi Pelaku yang Bekerja Sama di dalam Perkara Tindak Pidana Tertentu, yang selanjutnya disebut SEMA 4/2011.

Namun hingga kini aturan hukum yang ada belum benar mengatur tentang perlakuan kepada sorang justice collaborator. Peraturan yang ada pada saat ini hanya mengacu pada SEMA 4/2011 Perlakuan Bagi Wistleblowers dan Justice Collaborators dalam kasus tindak pidana tertentu sehingga aturan tersebut belum dimasukan dalam perundang-undangan yang secara khusus dan mengikat mengatur tentang perlakuan kepada seorang justice collaborator sehingga dalam berbagai kasus, sering kali para penegak hukum merespon berbeda-beda tentang keberadaan justice collaborator tersebut.

Lahirnya SEMA 4/2011 tersebut juga didasarkan pada pertimbangan bahwa dalam tindak pidana tertentu yang sifatnya serius seperti terorisme, kasus korupsi, peredaran narkotika, kasus pencucian uang dan juga tindak pidana perdagangan orang telah menimbulkan suatu ancaman yang berbahaya bagi masyarakat sehingga perlu ada perlakuan khusus kepada setiap orang yang melaporkan, mengetahui atau menemukan suatu tindak pidana yang dalam perjalananya dapat membantu para penegak hukum untuk menuntaskan dan mengungkapkan kasus tersebut secara jelas. Dan karena hal tersebut, untuk mengatasi tindak pidana tersebut, para pihak yang ikut terlibat dalam tindak pidana tersebut perlu mendapatkan suatu perlindungan hukum dan perlakuan khusus

Sementara itu, SEMA 4/2011 telah memberikan beberapa pedoman untuk menentukan kriteria apa saja bahwa seseorang bisa menjadi seorang justice collaborator, dalam beberapa kriteria berikut ini yaitu (1) Yang bersangkutan merupakan pelaku tindak pidana tertentu, serta mengakui kejahatannya, bukan merupakan dalang atau pelaku utama dalam kasus tersebut dan siap membantu hakim dengan memberikan keterangan yang valid 
dan dapat dipertanggungjawabkan sebagai saksi perkara pidana dalam proses peradilan tersebut". (2) JPU dalam tuntutannya menyatakan bahwa terdakwa telah memberikan keterangan valid, dapat dipertangungjawabkan dan buktibukti yang kuat sehingga para penyidik atau penuntut umum dapat mengungkap tindak pidana yang dimaksud secara tuntas, mengungkap pelaku lainnya yang memiliki peran lebih besar dan/atau mengembalikan aset - aset/hasil suatu tindak pidana". (3) Atas bantuan saksi pelaku tersebut, yang bersangkutan dalam hal seorang Justice Collaborator yang dimaksud seorang hakim dalam menjatuhkan dan menentukan pidana yang akan dijatuhkan dapat memberikan suatu pertimbangan seperti berikut :

i) Menjatuhkan pidana percobaan bersyarat khusus, atau

ii) Menjatuhkan pidana kurungan paling ringan diantara para terdakwa lainnya khususnya para pelaku utama yang telah terbukti secara sah dan meyakinkan bersalah dalam kasus tersebut dengan tetap memperhatikan juga

mempertimbangkan rasa keadilan.

SEMA 4/2011 dapat menjadi pedoman bagi hakim dalam memutuskan suatu perkara tindak pidana salah satu nya tindak pidana korupsi. Namun, banyak kelemahan dalam surat edaran yang dikeluarkan oleh mahkamah agung tersebut utamanya menyangkut suatu aturan dasar hukum bagi untuk memutuskan suatu perkara. SEMA masih hanya berupa imbauan, bukan suatu aturan perundang-undangan khusus yang mengikat, yang dapat menjadi suatu pedoman dasar bagi dalam memtuskan suatu perkara. Akibat kelemahan tersebut, beberapa hakim acap kali berbeda dalam mengambil suatu keputusan. Selain itu, Undang - Undang Nomor 13 Tahun 2006 tentang Lembaga Perlindungan Saksi dan Korban, yang selanjutnya disebut UU LPSK, juga tidak memberikan sebuah jaminan perlindungan hukum yang kuat terhadap justice collaborator. Dalam hal ini, KUHP dan KUHAP juga tidak mengatur posisi justice collaborator secara detail dan tuntas. 
SEMA 4/2011 tersebut tidak bisa menjadi suatu acuan yang kuat bagi jaksa maupun penyidik. SEMA lebih mengarah kepada suatu aturan bagi lingkungan peradilan, sehingga dalam implementasinya belum memilki sebuah kekuatan hukum tetap yang mengikat dan memastikan bahwa seorang justice collabolator dapat mendapatkan perlakuan khusus. Perlakuan khusus disini sangat penting mengingat dia bisa menjadi aktor utama pengungkapan kasus besar yang banyak merugikan keuangan negara sehingga kontribusi nya sangat besar untuk mengungkap siapa siapa saja yang terlibat dan bisa menyelamatkan uang negara.

Dalam menuntaskan berbagai kasus korupsi yang terjadi, tentu apresiasi perlu diberikan kepada Mahkamah Agung yang telah memberikan dasar atau acuan untuk menuntaskan berbagai perkara korupsi yang terjadi. Namun masih banyak sekali kelemahan dari surat edaran tersebut dilihat dari segi materil yaitu (1) Tidak ada aturan yang betul betul mengikat mengenai hak dan bentuk perlindungan seorang justice collaborator seperti apa, (2)
Kemungkinan keringanan pidana yang dijatuhkan hakim hanyalah berupa pertimbangan, bukan suatu keharusan yang harus dijalani dan diambil sehingga tidak memilki daya pengikat yang kuat.

Selain dari pada itu, SEMA 4/2011 juga masih memiliki banyak kekurangan utamanya apabila ditinjau dari segi formil diantaranya adalah aturan SEMA 4/2011 tersebut hanya hanya mengikat di kalangan internal Mahkamah Agung yakni Hakim sehingga dalam penerapannya, SEMA 4/2011 tersebut belum memberikan sebuah perlindungan hukum mengikat dan maksimal bagi para Justice Collaborator.

\section{Hambatan Dalam Perlindungan Hukum Bagi keberadaan Whistle Blower Dan Justice Collaborator Pada Pengungkapan Kasus Korupsi Di Indonesia}

Whistleblower dan saksi pelaku yang bekerjasama (Justice Collaborator) perlu mendapatkan sebuah perlindungan khusus agar mereka tidak merasa terbebani untuk membongkar semua kasus kejahatan tindak pidana korupsi sampai ke 
akarnya. Perlindungan ini mutlak diperlukan karena biasanya korupsi yang terjadi begitu rumit, melibatkan banyak orang, kelompok dan berbagai kepentingan di dalamnya. Korupsi yang terjadi adalah sangat terstruktur, masif, rapi, melibatkan banyak kepentingan di dalamnya. Saling menutupi satu sama lain agar kasusnya tidak terbongkar. Ketika salah satu penegak hukum misalnya KPK menangkap salah satu dalang dari korupsi tersebut, para penegak hukum perlu berkolaborasi dengan pelaku agar mau memberikan informasi yang relevan, valid, dan dapat dipertanggung jawabkan.

Apabila kasus yang terjadi melibatkan banyak petinggi negara yang mempunyai kedudukan dan kekuasaan penting dalam institusi negara. Mereka biasanya paham betul mengenai seluk beluk keuangan negara. Namun, dalam prakteknya, kerap terdapat hambatan yang bila ditinjau dari substansi hukum yang ternyata banyak kelemahan dalam pengaturan tentang justice collaborator tersebut dimana hanya diatur melalui SEMA 4/2011. Kelemahan ini utamanya menyangkut bahwa SEMA tersebut tidak mempunyai kekuatan hukum yang mengikat di bawah suatu perundang-undangan. Sementara itu ditinjau dari struktur hukum kelembagaan terkait dengan peran lembaga perlindungan saksi dan korban atau LPSK.

LPSK sendiri adalah suatu badan atau lembaga yang terbilang baru di Indonesia. LPSK sendiri berperan untuk memberikan suatu perlindungan dan penanganan khusus kepada justice collaborator dan tentunya harus didukung oleh penegak hukum. Ditinjau dari tugas dan wewenang yang dimiliki, LPSK sulit untuk mererapkan dalam hal kerja sama. Beberapa hal yang menjadi masalah LPSK adalah sebagai berikut (1) peran LPSK masih hanya sebatas menjalankan UU LPSK mengenai perlindungan terhadap saksi dan korban, dan belum membahas secara spesifik mengenai perlindungan kepada justice collaborator, (2) SEMA 4/2011 yang hanya sebatas himbauan bukan merupakan produk perundangundangan yang mempunyai kekuatan hukum yang mengikat, (3) Belum 
maksimalnya perlindungan terhadap whistleblower sehingga hakim sering mengabaikan rekomendasi aparat penegak hukum.

Menurut pakar hukum Dr. Ahmad Sofian, S.H, M.A, Memang setelah itu, muncul atau lahirlah norma yang mengatur tentang justice collaborator dimana UU No.13 tahun 2006 direvisi dan kemudian diganti dengan UU No.31 tahun 2014 khususnya pada Pasal 10 UU No. 31 Tahun 2014 tentang Perubahan UU No. 13 Tahun 2006 dengan isinya adalah sebagai berikut : (1) Saksi pelaku, korban dan juga saksi tidak dapat dituntut secara hukum, baik secara pidana maupun perdata menyangkut kesaksian yang telah diberikannya, kecuali kesaksian nya tersebut diberikan kepada hakim di pengadilan tidak dengan niatan sungguh sungguh atau itikad tidak baik, (2) Dalam suatu hal terdapat tuntutan hukum dari berbagai pihak terhadap Saksi, Korban atau Saksi Pelaku menyangkut kesaksian atau laporan yang akan, sedang atau telah diberikan, maka tuntutan hukum yang diajukan, wajib untuk ditunda hingga kasus tersebut diputus oleh pengadilan dan memperoleh kekuatan hukum tetap.

Kemudian dalam dalam Pasal 10

(A) KUHP menjelaskan:

1) "Seorang Justice Collaborator dapat diberikan penanganan secara khusus dalam proses pemeriksaan dan mendapatkan penghargaan atas kesediannya memberikan kesaksian sehingga kasus yang ada bisa selesai dengan tuntas dan terang benderang".

2) Penanganan secara khusus tersebut sebagaimana dimaksud pada ayat (1) berupa:

a) "Pemisahan tempat penahanan atau tempat menjalani pidana antara Saksi Pelaku dengan tersangka, terdakwa, dan/atau narapaidana yang diungkap tindak pidananya";

b) "Pemisahan pemeriksaan antara berkas Saksi Pelaku dengan berkas tersangka dan terdakwa dalam proses penyidikan, dan penuntutan atas tindak pidana yang diungkapkannya dan/atau":

c) "Memberikan kesaksian di 
depan persidangan tanpa prosedural formal akan selalu terjadi berhadapan langsung dengan jika revisi KUHAP yang secara tegas terdakwa yang diungkap mengatur tentang justice tindak pidananya". collaborator belum dilakukan Penghargaan atas kesaksian mengingat KUHAP merupakan sebagaimana dimaksud pada ayat (1) berupa :

a) Keringanan penjatuhan pidana; atau

norma hukum pidana formil, yang meletakan dasar-dasar yang kokoh dalam criminal justice system.

"Peraturan Bersama Menteri

b) Pembebasan bersyarat, remisi tambahan, dan hak narapidana lain sesuai dengan ketentuan peraturan perundang-undangan bagi Saksi Pelaku yang berstatus narapidana".

Walaupun ditinjau dari segi norma, justice collaborator telah diatur dalam UU PSK, tetapi dalam penerapannya masih perlu banyak yang dibenahi utamanya menyangkut kelemahan secara kekuatan hukum. Kelemahan itu berupa fakta bahwa justice collaborator tidak berada pada revisi KUHAP karena yang paling penting adalah meletakan dasar atau fondasi hukum yang kuat agar para penegak hukum Hukum dan HAM, Jaksa Agung, Kapolri, KPK, dan LPSK tentang Perlindungan Bagi Pelapor, Saksi Pelapor, dan Saksi Pelaku yang Bekerjasama juga belum maksimal untuk di implementasikan (lpsk.go.id 2013)". Perbedaan cara pandang yang terkadang berbeda dari para penegak hukum menjadi ganjalan dalam menjalankan aturan tentang saksi pelaku bekerja sama tersebut. Kemudian juga masih menurut Dr. Ahmad Sofian, S.H, M.A, "revisi UU No 31 tahun 2014 juga tidak memasukkan mengenai persyaratan sebagai pelaku yang bekerja sama sehingga rumusan syarat ini harus dicari padanannya dalam beberapa peraturan di luar UU”. (....)

mempunyai referensi dasar hukum yang kuat dalam mengambil sebuah keputusan. Oleh karena itu, kendala 


\section{Studi Kasus Kosasih Abbas}

Kosasih Abbas, yang pada waktu itu menjabat sebagai Kepala Sub Direktorat Energi Terbarukan kementrian ESDM ditangkap oleh Komisi Pemberantasan Korupsi dalam kasus korupsi proyek Solar Home System (SHS) di Kementerian ESDM tahun 2007 dan 2008. Pada saat itu, hakim memutuskan Kosasih bersalah dan menjatuhkan pidana penjara selama 4 tahun penjara dan denda Rp 250 juta subsider 3 bulan kurungan. Dia juga diminta membayar uang pengganti sebesar Rp.2,854 miliar atas kasusnya tersebut. Kosasih juga dikenakan pasal 2 ayat (1) jo Pasal $18 \mathrm{UU}$ Pemberantasan Tindak Pidana Korupsi, jis pasal 55 ayat (1) ke-1 KUHP jis Pasal 65 ayat (1) KUHP. Putusan tersebut banyak disesalkan oleh berbagai pihak mengingat dirinya pada saat itu menjadi justice collaborator.

Kosasih merasa perannya pada saat itu menjadi seorang justice collaborator tidak dipertimbangkan oleh hakim pengadilan. Pada saat sidang pembacaan pledoipun kosasih meminta hakim untuk memberikan putusan ringan kepada dirinya, mengingat perannya yang mau menjadi justice collaborator untuk mengungkap kasus korupsi yang terjadi dan pada saat itu pun kosasih mengungkapkan bahwa perannya pada saat itu hanyalah menjalankan perintah atasan.

Bahkan Pakar hukum pidana korupsi dari Universitas Indonesia, Akhiar Salmi, juga mengkhawatirkan soal putusan Kosasih. Menurut Akhiar Salmi berpendapat bahwa "majelis hakim terlalu formalis dan positivistik".(....) Sejatinya yang dilihat adalah asas manfaatnya, bahwa peran Kosasih telah mampu mengungkap kasus ini dengan terang dan jelas. Bisa dibayangkan jika tak ada justice collaborator, para terdakwa semua akan menjawab tidak tahu atau lupa. (https://nasional.kompas.com)

Tentu saja putusan ini menjadi sebuah preseden buruk bagi dunia Hukum di Indonesia. Terlepas dari kejahatannya, Kosasih telah bersedia untuk membeberkan kasus yang terjadi sehingga membuat masalah yang ada menjadi terang dan jelas. Kasus korupsi yang menimpa 
Kosasih Abbas menjadi pelajaran berharga bahwa SEMA 4/2011 belum dijalankan dan cenderung diabaikan. Putusan ini bisa berdampak tidak baik bila terjadi kasus serupa dimana terdakwa enggan untuk menjadi sorang justice collaborator karena menganggap statusnya tersebut tidak berdampak banyak pada putusan yang akan diberikan oleh hakim.

Sudah saat para penegak hukum dari berbagai instansi hukum untuk duduk bersama, berkolaborasi, dan menyamakan persepsi serta mengimplementasikan SEMA 4/2011 tersebut sebaik baiknya. Juga pihak yang terkait dalam hal ini instansi hukum, para praktisi hukum dan juga DPR duduk bersama untuk membahas pembentukan undangundang khusus yang secara tegas mengatur tentang Justice collaborator dan memasukannya kedalam KUHAP agar memiliki dasar hukum yang kuat sebagai referensi bagi hakim dalam menjatuhkan sebuah putusan hukum.

\section{Simpulan}

Berbagai kasus korupsi yang terjadi di Indonesia seolah menjadi sesuatu yang lumrah dan lazim terjadi. Sistem hukum yang lemah, kemudian juga Justifikasi atau stereotype bahwa hukum tajam ke bawah dan tumpul ke atas memang benar adanya meskipun tidak boleh men generalisasi, ditambah kebobrokan moral para perilaku elit elit kita di berbagai instansi atau lembaga pemerintahan seolah menambah preseden buruk dunia hukum kita.

Seorang justice collaborator adalah komponen penting dalam pengungkapan suatu kasus korupsi. Menjadi penting karena mereka ikut terlibat di dalam kasus tersebut dan dianggap yang paling mengetahui bagaimana kasus tersebut terjadi, siapa saja para pelakunya, dan kemana aliran dana yang yang mereka selewengkan. Seorang justice collaborator sejatinya harus mendapatkan suatu perlindungan khusus dari para penegak hukum yang ada agar mereka dapat membantu para hakim untuk mencari tahu fakta yang terjadi, mengingat 
banyak sekali kasus yang terjadi melibatkan banyak sekali kepentingan yang besar, banyak melibatkan elit di negara kita, orang yang mempunyai kekuasaaan besar di suatu lembaga atau instansi. Namun, dalam perjalanan nya, mereka sering merasa takut atau enggan untuk betul betul maksimal membantu penegak hukum membongkar kasus yang terjadi. Mereka merasa sering terancam baik secara individu, atau kerabat keluarga terdekatnya apabila memberikan kesaksian yang jelas dan tuntas di persidangan dari orang orang yang juga terlibat kasus di dalamnya untuk tidak membongkar kasus tersebut.

Hambatan tersebut pula juga diperkuat oleh sebuah fakta bahwa belum ada suatu undang - undang khusus yang mengatur tentang perlakuan bagi para Justice collaborator. Suatu undang - undang yang mempunyai substansi dan kekuatan hukum yang tetap dan kuat. Memang pada tahun 2011 lalu, pemerentah mengeluarkan SEMA 4/2011 yang mengatur tentang bagaimana perlakuan dan perlindungan bagi pelaku yang bekerja sama bagi keberadaan Whistleblower dan Justice Collaboratos pada pengungkapan korupsi.

Namun, apabila ditinjau dari substansi hukum, SEMA 4/2011 tersebut tidak benar-benar mengikat bagi para penegak hukum untuk mengambil suatu keputusan, sehingga SEMA tersebut dinilai masih sangat lemah karena tidak dimasukan ke dalam suatu perundang - undangan yang jelas khsusunya ke dalam KUHAP. Kasus yang menimpa Kosasih di atas tentu harus menjadi sebuah cerminan, perhatian dan pelajaran bagi perjalanan hukum kita di masa yang akan datang. Jangan sampai, seorang justice collaborator yang kesaksiannya sangat diperlukan untuk membantu para penegak hukum membuka suatu kasus korupsi, diperberat hukumannya. Tentu kita harus menilai manfaat yang kita dapat dari seorang justice collaborator ia dapat membuat suatu kasus korupsi menjadi terang benderang dan juga mampu menyelamatkan uang negara yang 
sangat besar. Apresiasi berupa hukuman ringan perlu menjadi perhatian bagi para hakim, dengan mengimplementasikan SEMA tersebut sebaik-baiknya. Dari hasil yang ada pada seperti yang telah dijelaskan pada latar belakang dan pembahasan, penulis dapat menyarankan beberapa hal diantaranya (1) terbongkarnya suatu kasus korupsi salah satunya tidak lepas dari orang orang yang terlibat di dalamnya. Saksi pelaku bekerja sama atau seorang justice collaborator merupakan suatu komponen penting pengungkapan kasus tindak pindak korupsi. Sudah seyogyanya aparat penegak hukum memberikan sebuah apresiasi berupa keringanan hukuman yang didapatkannya sebagai implementasi dari SEMA4/2011. Perlakuan ini bukan untuk membenarkan perlakuan yang diperbuatnya, apapun alasannya, korupsi adalah tindakan yang sangat tidak dibenarkan. Namun, dengan justice collaborator tersebut azas manfaat yang didapatkan sangat besar, banyak uang negara yang bisa terselamatkan, juga para pelaku seluruhnya bisa diungkap dengan tuntas khusunya para pelaku utama, (2) Para penegak hukum perlu duduk bersama, menyatukan pemahaman dan persepsi tentang Justice collaborator tersebut. Karena apabila surat edaran tersebut di implementasikan secara baik, maka manfaat nya akan sangat besar. Para hakim pengadilan pun harus mampu melepaskan tekanan besar yang dialamatkan kepadanya dalam membuat suatu putusan sidang. Namun, tentu SEMA 4/2011 tersebut ditinjau dari sisi substansi hukum masih sangat lemah karena tidak dimasukkan ke dalam suatu peraturan perundang-undangan. Perlu dibuat suatu undang-undang khusus dan memasukan nya dalam revisi KUHAP karena KUHAP merupakan norma hukum pidana formil, yang meletakkan dasar-dasar yang kokoh dalam criminal justice system.

\section{Daftar Pustaka}

\section{Buku}

Chazawi, Adami, (2006), Hukum Pembuktian Tindak Pidana Korupsi, Jakarta, Refika Aditama.

Sofian, Ahmad, (2014), Kausalitas 
dalam RUU-KUHP, Jakarta, Institute for Criminal Justice Reform.

Ali, Mahrus, (2012), Dasar-Dasar Hukum Pidana Indonesia, Jakarta, Sinar Grafika.

\section{Jurnal}

Manalu, River Yohanes, (2015), Lex Crimen Volume IV Nomor 1.

Nixson, (2013), Perlindungan Hukum Terhadap

Whistleblower dan Justice Collaborator, USU Law Jurnal Volume 1 Nomor 2.

Suratno, (2017) Perlindungan Hukum Saksi dan Korban Sebagai Whistleblower dan Justice collaborators Pada Pengungkapan Kasus Korupsi Berbasis Nilai Keadilan, Jurnal Pembaharuan Hukum Volume IV Nomor 1.

\section{Website tanpa author}

http://business-

law.binus.ac.id/2018/02/14/ju stice-collaborator-danperlindungan-hukumnya/.

http://www.zonalima.com/artikel/59 04/Pelapor-dan-JusticeCollaborator-Masih-RentanDikriminalisasi.

https://nasional.kompas.com/read/20 13/02/08/01544915/Preseden. Buruk.Kasus Kosasih.

https://lk2fhui.law.ui.ac.id/penerapan -justice-collaborator-dalamperkara-tindak-pidana-
korupsi-di-Indonesia/

Peraturan Perundang - Undangan Undang - Undang Republik Indonesia Nomor 13 Tahun 2006 Tentang Perlindungan Saksi Dan Korban.

Undang - Undang Republik Indonesia Nomor 31 Tahun 2014 Tentang Perubahan Atas Undang-Undang Nomor 13 Tahun 2006 Tentang Perlindungan Saksi Dan Korban.

Surat Edaran Mahkamah Agung Nomor 4 Tahun 2011 tentang Perlakuan Bagi Pelapor Tindak Pidana dan Saksi Pelaku yang Bekerja Sama di dalam Perkara Tindak Pidana Tertentu. 